\title{
The European Company: Original expectations and deficiencies of implementation
}

European Journal of Industrial Relations 2020, Vol. 26(I) 23-39

(C) The Author(s) 2019

Article reuse guidelines: sagepub.com/journals-permissions DOI: I0.1 I77/0959680। I8825057

journals.sagepub.com/home/ejd

\section{Berndt Keller}

Universität Konstanz, Germany

\section{Sophie Rosenbohm}

Universität Duisburg-Essen, Germany

\begin{abstract}
We address the failures of the implementation of the European Company Directive and their farreaching consequences, and discuss options for necessary amendments and improvements. We present empirical data on the characteristics of European companies and their distribution across EU Member States, and discuss major unexpected results of transposition and implementation as well as many evident problems. We then develop options for amendments, including definition of structural changes, mandatory introduction of employee involvement and extension of the 'before and after' principle. Finally, we analyse the history of the review process and explain why amendments have not and will most likely not be introduced despite obvious failures and deficiencies.
\end{abstract}

\section{Keywords}

Employee involvement, EU company law, European Company, European industrial relations, Europeanization, Societas Europaea (SE)

\section{Introduction}

The European Company (Societas Europaea, SE) is a new supranational legal form of corporate governance. Its legal framework consists of two intertwined parts, the European Company Statute Regulation (hereafter ECS) and the supplementary Directive on employee involvement, both adopted in 2001 and required to be implemented by all Member States by 2004. The latter demands obligatory negotiations on employee

\section{Corresponding author:}

Sophie Rosenbohm, Institut Arbeit und Qualifikation (IAQ), Universität Duisburg-Essen, 47048 Duisburg, Germany.

Email: sophie.rosenbohm@uni-due.de 
information and consultation at the company level before an SE is established. It is of special importance and interest for our article.

The plan to introduce the SE as a transnational company form had been on the EU political agenda since the late 1960s. The legislation is strongly related to the completion of the internal market, and its main aim has been to make it easier for companies to organize their cross-border business without restrictions by different national regulations. However, with its provisions on employee involvement, it was supposed to set new grounds for the development of European industrial relations and, thus, to constitute an integral part of 'social Europe'.

There were more than three decades of controversy, lengthy periods of stagnation and multiple variations of political strategy, especially about the principles and extent of employee involvement. Initially, it was planned to establish a unitary system of employee participation by means of binding legislation at the EU level. These ambitious plans had to be changed towards expanding flexibility and the primacy of negotiated agreements at the individual company level. The protection of national systems with established rights was a core issue in the contested debate over the Directive, and deviations from wellestablished standards were by no means an intended consequence. The procedural instead of substantive outcome, and at the same time a sophisticated political compromise, resulted in far-reaching voluntarism, complexity and heterogeneity instead of the originally intended binding unity and homogeneity. ${ }^{1}$

SE research has followed the stages of the policy cycle (agenda-setting, formulation, adoption, implementation and evaluation). Three phases can be clearly distinguished. The original focus of interest was on different stages of the protracted history of nondecisions (Keller, 2002; Gold and Schwimbersky, 2008) as well as sophisticated legal problems (Höland, 2000; Weiss, 2008). After SEs were established, quantitative as well as qualitative research, especially numerous case studies, examined formal aspects such as establishment of SE works councils (hereafter SEWCs), their composition and chairs, impact of select committees, number of annual meetings, number of external experts and union officials and employee representation at the board level (Keller and Werner, 2012; Rehfeldt et al., 2011; Rosenbohm, 2014). Most recently, the actual functioning and daily work of SEWCs and board-level employee representation has been analysed in more detail (Casey et al., 2016; Rosenbohm, 2013; Waddington and Conchon, 2017).

However, originally unexpected outcomes or definitely unintended consequences have occurred but have so far received hardly any attention. Therefore, our special emphasis is not on legal expertise but on these rather extraordinary long-term developments. We aim to bring attention to the failures and problems of transposition and implementation and also to discuss options for amendments and improvements. We first present the most recent empirical data, then elaborate on results of transposition as well as implementation and the major obvious deficiencies. After this we indicate the most important potential remedies, and explain why no political measures have been taken and the lasting political stalemate.

We make extensive use of the ETUI (2018) European Company database (hereafter ECDB) for the quantitative part of our study. There is, perhaps surprisingly, no official European registry for SEs, so the ETUI has collected information on registered SEs. The publicly available ECDB is the only reliable quantitative source of reference and 
Table I. Number of registered SEs and new registrations, 2004-20I7.

\begin{tabular}{lccc}
\hline & $\begin{array}{l}\text { Registered } \\
\text { SEs }\end{array}$ & $\begin{array}{l}\text { New registrations } \\
\text { (all SEs) }\end{array}$ & $\begin{array}{l}\text { New registrations } \\
\text { (normal SEs) }\end{array}$ \\
\hline 2004 & 6 & 6 & 2 \\
2005 & 16 & 10 & 5 \\
2006 & 41 & 25 & 15 \\
2007 & 109 & 68 & 36 \\
2008 & 261 & 152 & 47 \\
2009 & 410 & 149 & 41 \\
2010 & 598 & 188 & 41 \\
2011 & 939 & 341 & 57 \\
2012 & 1449 & 510 & 57 \\
2013 & 1899 & 450 & 57 \\
2014 & 2159 & 260 & 37 \\
2015 & 2396 & 237 & 39 \\
2016 & 2632 & 236 & 49 \\
2017 & 2923 & 291 & 57 \\
\hline
\end{tabular}

Source: own compilation, ECDB 07/2018.

incorporates extensive information on our issues. We cover the complete time period since 2004 when the first SEs were established until mid-2018. In addition, we analyse publicly available documents.

\section{Empirical data and some consequences}

\section{SE facts and figures: state of the art}

The ECDB distinguishes three different, by now widely acknowledged forms of SEs: companies with operations and more than five employees (normal SEs), companies with operations but no or very few employees (micro/empty SEs) and companies where there is insufficient information for classification (UFO SEs). ${ }^{2}$

We focus on the development of normal SEs (with actual operations and at least five employees), but return to the other widespread forms for comparative purposes. In this regard it is important to realize from the very beginning that the SE Directive explicitly intended to provide various procedures of information and consultation for all SEs and did not (or could not) take these various forms of establishment and their negative consequences for employee involvement into regard. In other words, the original aim has been reached only in a limited number of SEs, and unintended consequences happen frequently.

Table 1 indicates that the SEs had a rather slow start due to a lack of information about the opportunities, limited experience and unresolved legal questions (Stollt and Kelemen, 2013); but the number of newly registered SEs increased more or less steadily until 2012. There was then a decline in new registrations. By mid-2018 a total of 3044 SEs were listed in the ECDB. 
Table 2. Geographical coverage of all registered and 'normal' SEs.

\begin{tabular}{lclllllll}
\hline & SE & Normal & & SE & Normal & & SE & Normal \\
\hline CZ & 2121 & 97 & CY & 25 & 10 & PL & 6 & 2 \\
DE & 526 & 308 & AT & 17 & 11 & HU & 5 & 5 \\
SK & 147 & 18 & LI & 11 & 4 & SE & 5 & 2 \\
UK & 38 & 13 & IE & 10 & 2 & NO & 3 & 2 \\
FR & 36 & 27 & EE & 7 & 6 & IT & 3 & 1 \\
NL & 31 & 22 & BE & 6 & 4 & BG & 3 & I \\
LU & 30 & 12 & LV & 6 & 4 & Other & 8 & 2 \\
\hline
\end{tabular}

aES, FI, LT, PT, DK, GR, SI.

Source: own compilation, ECDB 07/2018.

The growth period was mainly driven by the high number of newly registered SEs in the Czech Republic, accounting for more than 80 percent of all new SEs in 2011-2013. One driving force was that small Czech companies used the SE regulations for a simplified corporate structure in order to avoid stricter national obligations (Cremers and Carlson, 2013). Since then the number of SE registrations in the Czech Republic has fallen significantly, which may be linked to changes in the domestic law (Eidenmüller and Lasák, 2012; Lasák, 2018); this also explains the overall decline of newly registered SEs in the recent past.

Remarkably, only 553 SEs (18\%) have so far been identified as 'normal SEs'. Compared with the overall number, the number of newly registered normal SEs has remained fairly stable in recent years. Whether this present number is considered high or low depends on the observer's original expectations and categories of judgement. SEs are currently registered in 27 of the 31 Member States of the European Economic Area (EEA). However, they are very unevenly distributed (see Table 2). The Czech Republic (70\%) and Germany (17\%) account for more than 80 percent of all currently existing SEs.

This skewed distribution is even more evident if we focus on normal SEs: more than half are registered in Germany (56\%), followed by the Czech Republic (18\%), France $(5 \%)$ and the Netherlands (4\%). Thus, extensive interest in establishing SEs is restricted to a small number of EU Member States. Most Central and Eastern European countries are absent from the list. An economic explanation is that more SEs are to be expected in countries with strict national legislation on employee involvement, because EU regulation introduces incentives for more flexibility and tailor-made arrangements (Weiß, 2016). We come back to the consequences of these national peculiarities later on.

Furthermore, there are no clear trends with regard to sectors of economic activity or company size. Normal SEs are established most frequently in financial and commercial services, but also in the metal and chemical sectors. The legislation sets no size threshold for the establishment of SEs. There are indeed SEs of all sizes (in terms of employees) ranging from small family owned and medium-sized enterprises to large multinational corporations (MNCs) such as Allianz, BASF or Bilfinger. In contrast to 
frequent earlier assumptions it should be recognized, however, that there is no clear dominance of large MNCs.

According to the SE Regulation, four forms of establishment are distinguished: by merger, the creation of joint holding company, the creation of a subsidiary and the conversion of a single company into an SE. A cross-border character is a necessary prerequisite for all these forms. In addition, an SE itself can be used to create a subsidiary SE; in this case, however, no cross-border element is required because the SE itself is already a supranational legal company. Our analysis shows another very uneven distribution: the vast majority of SEs (2425) were set up as a subsidiary, 233 by conversion, 135 by merger and only 13 by creating a joint holding company. For another 244 companies, no information is available. A similar distribution results when the analysis is limited to normal SEs. Here, too, most are established through a subsidiary (232 or 42\%) or by conversion (190 or $34 \%$ ), whereas mergers and holding companies are again far less common.

It is unexpected and even striking that the creation of a subsidiary has turned out to be the most popular form of establishment, although the ECS was not originally intended to institutionalize this specific form. As our further analysis indicates, the dominance of subsidiary SEs is mainly linked to the activation of non-operational shelf SEs. We come back to this problem later on.

According to the ECS, an SE may only be registered after management and employees, represented by a special negotiating body (SNB), have tried to conclude an agreement on arrangements for employee involvement. Management has to launch this obligatory procedure. There are three possible outcomes of these negotiations on questions of crossborder nature: the SNB may decide not to open or to terminate negotiations, both sides conclude an agreement or the standard rules (or statutory fall-back provisions) will apply if both sides cannot reach an agreement. In general, two statutory forms of employee involvement are negotiable: a transnational employee information and consultation procedure or body (SEWC), or, for the first time in the EU industrial relations history, employee representation in the administrative or supervisory board of the SE.

The SE Directive explicitly states that information and consultation procedures should be ensured in all cases. However, our analysis reveals that these two forms exist only in a minority of normal SEs. By mid-2018 only 26 percent (146) had introduced information and consultation procedures, and in 13 percent (73) management and employee representatives had additionally agreed on board-level representation. Overall, the vast majority of SEs with employee involvement rights (around $80 \%$ in both cases) had their headquarters in Germany.

In most companies, management and employee representatives have concluded an agreement, whereas the standard rules have only been applied in two cases. More detailed analyses of SE agreements show that the majority adhere closely to the subsidiary legal provisions (De Spiegelaere and Jagodziński, 2015; Rose, 2013). In addition, case studies have revealed a strong influence of the standard rules as they represent for both sides the main reference point during the negotiation process (Rehfeldt et al., 2011; Rosenbohm, 2014). Nevertheless, in some respects, especially with regard to the SEWC competences, there are notable deviations from the subsidiary provisions, some going beyond these and others falling behind (De Spiegelaere and Jagodziński, 2015: 26, 45-46; Rose, 2013: $210,214)$. Exact numbers cannot be indicated because rights of employee involvement 
differ in various regards, for example, according to the number of regular and/or extraordinary meetings.

In companies with no such agreements on transnational employee involvement, the SNB either did not commence or terminated the negotiations, or no negotiations took place. Consequently, employees of these companies do not have access to any kind of interest representation at the SE level, although they work in an MNC that is incorporated under European law. The case of no negotiations is especially relevant if an SE has no employees at the moment of establishment, because without employees no negotiations can be held.

\section{Some original expectations and concerns}

Various fears about the potential consequences of this new multi-level form of European corporate governance had been disputed before the ECS was finally adopted. However, empirical research does not validate all these fears. We discuss three interrelated aspects: the SE distribution across Member States, forms of employee representation and board size, and board structure and (re)location of registered offices.

\section{Distribution across Member States}

As already mentioned, most normal SEs have their registered headquarters in Germany. Originally, German employers and their interest associations complained that German companies would suffer severe competitive disadvantages in establishing SEs because of the requirement to maintain their comparatively advanced national rights of codetermination. Employers' associations and some corporate governance lawyers demanded that these rights should be curtailed or even abolished (Arbeitskreis Unternehmerische Mitbestimmung, 2009; BDA/BDI, 2004; Von Werder, 2004). Obviously, these worries concerning location disadvantages or site burdens (Standortnachteile) proved unjustified; rather, the exact opposite has happened. Nevertheless, the demands for an 'opening' of existing legal forms, especially parity provisions on the board, have been renewed from time to time.

\section{Forms of employee representation and board size}

For many years the controversy about the SE establishment focused on the board-level representation that exists only in a certain number of EU Member States, in particular Germany (Gold, 2011; Waddington and Conchon, 2017). In numerical terms, procedures of information and consultation are more common and thus more important for SEs. As already indicated, the number of SEs with transnational information and consultation rights (146) is twice as high as the number that have additionally implemented boardlevel employee representation (73).

In one specific regard, the SE has clearly triggered the spread of European information and consultation bodies across MNCs; only a small number (29) had a European Works Council (EWC) before transforming into an SE (Rosenbohm, 2013). Against the background of the long and contested debate about board-level employee representation within SEs, this development constitutes an additional unexpected outcome. 
A related dispute deals with the size and composition of supervisory boards and the effects of SEs on employee representation. The debate has long been dominated by the view that SEs will have far-reaching implications as they may threaten and undermine national forms of board-level representation. Furthermore, some SEs boards consist of fewer members because of the frequent and popular (but in empirical terms unjustified) assumption that smaller boards are more efficient.

As demonstrated above, only 73 companies have implemented board-level employee representation and $58(79 \%)$ of these are located in Germany. Their board size ranges from 3 to 20, with an average of nine members. There is no clear trend towards reducing board size by transforming into an SE; despite the assumed effect of easier coordination this has occurred only in five cases. However, this tendency is not necessarily a weakening of participation rights as shareholders and employees are equally affected (Keller and Werner, 2010). Overall, companies with parity codetermination tend to have larger supervisory boards than those with a lower level of employee representation.

A little less than one-third of German-based SEs provides for parity codetermination, whereas the others have (at least) one-third participation. A recent analysis of all normal SEs (Rosenbohm, 2014) highlights the fact that formerly existing board-level employee representation is reproduced in the $\mathrm{SE}$ with the same proportion. The reason is a peculiarity of the SE Directive: the 'before and after' principle, formerly unknown, specifies that all existing national levels are to be maintained if an SE is established. The practical consequence is that board-level employee representation has been mainly retained.

It is important, however, to note that this continuity has been accompanied by changes regarding the internal composition of board-level employee representatives. These variations have two dimensions. One is whether representatives comprise only employees or can include external trade union officials, as is possible under German law. The other is the 'internationalization' of representation, because SE legislation has created the option to include representatives from different European countries on company boards.

In 12 SEs with parity board-level representation, the number of external union representatives has decreased; thus the impact of unions that are represented in the company has been reduced. Simultaneously, an internationalization of board-level employee representation has occurred. Our analysis reveals a marked difference between the companies with parity and those with one-third participation. The former group mostly includes external union representatives. However, this is not the case for the latter (the majority).

A quite similar distribution appears for the internationalization of board-level employee representation that is, with few exceptions, restricted to those companies with parity representation. Overall, employee representatives from at least two European countries are members of the supervisory boards in 88 percent (14) of the companies with parity codetermination, whereas this is only the case for around 14 percent (8) of those with non-parity representation.

These statistics constitute another surprise: Europeanization of participation rights is limited to a small group of SEs, mainly those with former parity codetermination, and path dependencies of national 'custom and practice' still prevail. A recent study concludes that

the findings demonstrate that board-level employee representation in SEs is best defined as being located at the intersection of German and European practices. Beyond the practices 
board-level employee representation shares with both German parity codetermination and onethird codetermination, board-level employee representation in SEs also displays its own specific characteristics. (Waddington and Conchon, 2017: 4)

In most cases the preservation of status quo ante arrangements is the obvious outcome. All in all, the introduction of SEs initiates neither a 'race to the bottom' nor 'a race to the top' of employee involvement. The overall distribution 'reveals an ambiguous picture' and 'a mixed balance with regard to employee involvement' (Stollt and Kelemen, 2013: 44-45).

\section{Board structure and (re-)location of registered offices}

At the national level, there exist dualistic and monistic forms of employment relations (Bamber et al., 2016; Frege and Kelly, 2014). There are also dualistic (or two-tier) and monistic (or single-tier) forms of corporate governance. The SE Directive allows, unlike national regulation in the majority of EU Member States, the free choice of systems (management board and supervisory board according to the Western European model vs administrative board/board of directors according to the Anglo-Saxon model). The reason for this mutual recognition of national regulations is a compromise of political nature: any decision for one or the other model could not have achieved the necessary political majority; thus 'flexibility' and the unrestricted 'choice of systems' had to be introduced. The final decision is made by the general meeting of shareholders and thus without any involvement of employee representatives.

In numerical terms the majority $(62 \%)$ of normal SEs follows the dualistic pattern. There is, in contrast to some original expectations, no general trend towards unitary boards. Quite the contrary, the majority follows the 'country-of-origin' principle. Theoretically, there is no general and overall advantage of one or the other variant. The ECDB shows that all SEs with employee representation have a two-tier structure.

According to the ECS the relocation of headquarters from one Member State to another is legally possible. This new option of flexibility establishes the 'exit threat' for companies. Before the ECS was passed, repeated fears assumed that newly established SEs would make frequent use of this option, among other reasons, because of major differences in the national tax regimes. However, the ECS stipulates that the SE registered office and head office must always be located in the same Member State.

In any event, such cross-border mobility for economic and tax competition reasons has happened less frequently than expected and is, therefore, less serious an issue than originally predicted. According to the ECDB, 112 companies - among them 38 percent of normal SEs - have made use of this option. Thus, despite simplified procedures this decision constitutes a rather rare and exceptional case. Again, national 'custom and practice' still exerts the major impact at the supranational level.

\section{Results of implementation and their obvious deficiencies}

We know from existing research that during the implementation processes of numerous EU regulations, difficulties in different social policy and industrial relations fields 
are by no means unusual (Falkner et al., 2005). Nowadays, various results of SE implementation can be identified. Their deficiencies need special attention. If they are not removed they have long-lasting consequences, exert substantial impact at lower levels and put the initial objectives at risk. In the SE case, these problems are obvious because, as already indicated, less than one-fifth of all existing SEs have been identified as normal ones despite the fact that their establishment was the focal intent. In other words, the major unexpected outcome and surprising lack of implementation is the high number of non-normal SEs.

These major differences are caused, first, by various forms of quite 'flexible' countryspecific transposition laws that have to be distinguished from later implementation procedures, by special interests of various national stakeholders and their lobbying activities, by the perceived importance of the specific topic as well as by legal-institutional differences between EU Member States, especially their industrial relations and corporate governance systems (Weber, 2013). In our case, implementation does not happen at the sectoral but at the individual company level.

\section{Shelf and empty SEs}

The high number of shelf and empty SEs, 'the creation of which has become a specialist industry' (Rehfeldt et al., 2011: 67), constitutes a major surprise. These forms are, for at least some companies, attractive legal vehicles but were originally neither intended nor expected. Their reasons are obvious: 'SE creation is proving to be a happy hunting ground for consultants and legal services, and in fact many of them participated in the consultation procedure, using it as a marketing instrument ... or for lobbying purposes' (Cremers, 2011: 272).

As mentioned above, according to the ECS normal SEs can only be registered after an agreement on employee involvement has been concluded. Management has to negotiate on all relevant issues with the SNB, the elected or appointed representative organ of employees from all countries affected. This provision for proportional representation of the overall workforce is supposed to protect existing employees' rights and interests from being either eroded or neglected.

The problem is that the Directive lacks exact and unambiguous prescriptions on the introduction of employee involvement rights in cases of delayed establishment, that is, when shelf or empty SEs are activated and converted into normal ones. It has been possible to activate empty SEs without initiating negotiations about employee involvement (Von der Höh, 2017). Thus, the prevalence of shelf SEs represents a considerable threat to these rights. It is estimated that around 40 percent of all normal SEs in Germany are activated shelf SEs (Hans-Böckler-Stiftung, 2018). A higher regional court in Germany decided in 2009 that the entitlement to negotiations is generally revived when an SE is activated, but this remains a controversial issue, and it is legally questionable what exact circumstances constitute such an instance (Köstler, 2013). The number of activated shelf SEs and the significant number of SEs without any kind of transnational rights of employee involvement indicate significant implementation problems: the intent of the SE Directive is at least subverted if not even reversed. For the time being, not all SEs are treated the same. 


\section{Motives for SE establishment and preservation of the status quo ante}

Motives for the establishment of an SE include substantial savings in ex ante and ex post transaction costs, differences in national tax systems, national company laws or corporate restructuring. The 'before and after' principle in the SE Directive requires that all former national standards of employee involvement be maintained, but restricts this obligation to protect acquired rights exclusively to the date of foundation.

Various efforts of strategic escape and specific forms of 'regime shopping' relate more frequently to board-level representation than to information and consultation procedures. In some cases, SEs, especially those with headquarters in Germany, have been used to circumvent existing national participation rights or to 'freeze' them at a lower level (Köstler, 2013; Rosenbohm, 2014). Our research, based on the employment figures published in the SE foundation plans, reveals that at least 20 German companies were transformed into an SE shortly before they were due to reach the threshold of 2000 employees, which normally triggers the right to parity board-level employee representation. By transforming into an $\mathrm{SE}$, these companies either prevented any kind of board-level involvement or preserved a lower level than prescribed in their domestic participation laws.

Such a 'pre-emptive escape from participation' that has occurred in individual cases was definitely not intended by the SE Directive. A similar problem is the conservation of existing levels of employee involvement if the number of employees increases after SE establishment. The Directive contains provisions only for the date of establishment but no unambiguous prescriptions for later developments, although they may have negative repercussions. Thus, the current version of the 'before and after' principle, which was originally introduced to safeguard existing employee participation rights, can also have the opposite consequence. Furthermore, the definition of 'structural changes' considered to be necessary to trigger renegotiations about employee involvement remains rather vague and indeterminate in the Directive as well as in most national transposition laws.

\section{What should be done?}

Our research demonstrates serious deficiencies at different levels, the SE Directive itself, transposition laws at the national level as well as implementation procedures at the individual company level. The original substance of the SE Directive that already represents the lowest common political denominator is watered down by unanticipated strategies that lead to non-intended outcomes. In at least some cases the outcome turned out to be even the exact opposite of the original intent.

The developments analysed lead to the question: what should be done to remedy these defects? We therefore turn from the empirical-descriptive to the normative level of analysis. The original intention was that no avoidance of national rules should be allowed. The decisive question is how the deviations we have described from the original intentions and concerns of the Directive could either be prevented from the beginning, or at least remedied later on. The aim should be to close existing legal loopholes, avoid obvious inconsistencies and guarantee that the goals that are indicated in the Directive are actually reached. Therefore, the Directive needs to be amended and adapted in some focal regards. It needs more dynamic concepts instead of the existing static ones. 
Our proposals for re-regulation aim to remedy existing deficiencies. We elaborate on the most urgent: structural changes and their consequences (thresholds for employee involvement and the 'before and after' principle) and activation of non-operational shelf and empty SEs (negotiations about employee involvement). We focus on these clusters of issues and do not deal with others such as demands for an official EU registry for all SEs, creation of a monitoring service, dismissal protection for employee representatives or fines for non-compliance.

\section{Structural changes and their consequences}

One decisive problem is that the connotation of 'structural changes' at a later point of time (such as considerable changes in the number of employees, merger with or acquisition of another company, transnational corporate restructuring) is not clearly specified in the Directive or in most transposition laws (Stollt and Kluge, 2011). The Commission itself argues that the 'before and after' principle should apply 'not only to the initial establishment of an SE but also to structural changes in an existing SE and to the companies affected by structural change processes' (SE Directive, Recital 18). Legal expertise disagrees about the exact interpretation.

One major gap in the Directive is the fact that it does not provide specific rules for the possibility that the number of employees increases after the formation of the SE. In these cases of major structural changes, there are two options of an obligatory nature for changes in the Directive concerning employee involvement: a new SNB could be established according to the now valid principle of proportional representation and negotiate with management. Or the already existing SEWC could lead these negotiations (as prescribed in German legislation, but not mentioned in the Directive). The second option is to be preferred because it is easier to implement, whereas the first would create additional organizational delays and substantial problems.

The definition of exact thresholds is of course debatable and would constitute the outcome of another political compromise. Such 'salient points' need to be fixed but cannot simply copy any national pattern because of their huge differences. This procedural adaptation could be fixed in a changed SE Directive or negotiated at the individual company level between the formerly established SNB and the management. However, individual tailor-made agreements, if concluded at all, would have limited decentralized coverage and could therefore not substitute for generally binding changes in the Directive.

The ETUC (2014) has adopted a framework resolution that calls for a Directive introducing a new and integrated architecture for workers' involvement in European company forms. This initiative aims to introduce an obligation to implement board-level employee representation in all European company forms, including the SE. This proposal is accompanied by a so-called escalator approach linking the level of participation to the number of employees within the company and its subsidiaries.

\section{Activation of SEs and negotiations about employee involvement}

As described, normal SEs are not the majority of existing SEs. Any attempt to outlaw the nowadays common practice of establishing shelf and empty SEs would not be realistic, 
although originally the ECS did not intend to institutionalize these forms. Such SEs were usually registered without negotiations about employee involvement. The question is what measures should be taken in cases of their later activation. For the time being, there exists, for whatever reasons, no legal procedure for establishing rights of employee involvement. The rules of the Directive are restricted to the time of foundation and, are therefore, inadequate.

Our proposal is that the introduction of an SNB to negotiate with management and to conclude an agreement should also be mandatory for these cases. If both sides do not reach an agreement, the SE should not be allowed to be activated, or the minimum standards defined in the Directive should be applied. Thus, all SEs that are normal from the beginning as well as other SEs that are normalized later would be treated the same, preventing what are now frequent efforts to circumvent or manipulate the Directive. Currently, sufficient control mechanisms are lacking.

\section{The political context}

\section{Some stylized facts on the (non-)initiated review}

According to the SE Regulation, the review of the ECS was due 5 years after it came into force (Cremers, 2013b; Schwimbersky and Gold, 2013). In 2008, the Commission published a Communication that reviewed the application of the Directive with a view to proposing any necessary amendments (COM (2008)591 final). The reaction of both social partners was that no major amendments or clarifications were necessary (Cremers, 2013b).

Next, the Commission contracted a report on the application of the Regulation and proposals for amendments to be provided by independent experts (Ernst \& Young, 2009). In early 2010, the Commission made this consultation document available, launched an online consultation on its results and, later on, published its own summary of the comments (European Commission, 2010). Among the criticisms were that that the Ernst \& Young study did not address well-known developments such as the unexpectedly high number of non-operational shelf SEs in contrast to normal ones, ignored substantial research on employee involvement and adopted a methodology that was seriously deficient (Cremers, 2011, 2013b; Cremers et al., 2010). In late 2010, the Commission presented a Report to the European Parliament and the Council on the application of the Regulation on the Statute for an SE (COM(2010)676 final).

In mid-2011, the Commission initiated a formal first-phase consultation of the European social partners on the possible review of the SE Directive. The answers of 'both sides of industry' differed significantly: BusinessEurope complained about provisions of the SE Directive, such as the requirement to set up an SNB, demanded more flexibility and recommended the simplification of the SE Regulation. The ETUC prioritized continued dialogue on improving all SE rules and criticized the foundation of empty and shelf SEs. In mid-2011, the Commission approved the consultation document.

Later on, the Commission decided not to take the initiative. The Action Plan on EU Company Law and Governance, published in late 2012, included no proposals for revision 
of the Directive or Regulation. The Commission argued that the expected benefits of a revision would not outweigh the potential challenges involved in reopening the discussions $(\operatorname{COM}(2012) 740$ final). Since then the problem of necessary amendments has faded from the political agenda. ${ }^{3}$

\section{The reasons for non-decisions}

One could argue that only 5 years after coming into effect it was indeed too early to review the SE Directive. One plausible explanation is that processes of transposition that were supposed to be completed within 3 years were considerably delayed in a number of Member States until 2007, because of lack of interest (Fulton, 2013). Furthermore, sufficient practical experience with the application of the Directive was not yet available. Therefore, it was understandable that amendments were supposed to be postponed for some time - but not indefinitely.

However, no subsequent political initiative has been taken. The resulting problem is that the longer the delay before initiating necessary amendments, the more originally unintended effects occur, while the intended opportunities for pattern-setting are not realized. The typical, officially proposed measures, such as the exchange of best practice, capacity-building of stakeholders and financial support for projects, prove insufficient for achieving the necessary improvements.

The problem is that, at least for the time being, a long-lasting political stalemate has been created because of differing, sometimes even opposing interests between Member States and various groups of stakeholders, including national social partners and shareholders. There are several reasons for this lasting deadlock:

First, as already described, the vast majority of normal SEs have their registered office in Germany. In many Member States, especially those with no tradition of far-reaching and statutory employee involvement, there are very few or even no SEs at all (Stollt and Kelemen, 2013). Because of this unequal distribution across Member States and the continued lack of interest in this issue in at least some, there exists no critical mass of active proponents willing to push for amendments. In at least some of these Member States, various stakeholders might also oppose any modifications.

Second, as already mentioned, the European social partners were officially consulted by the Commission on a review of the Directive but expressed opposing views on the need for amendments, especially regarding (almost all) issues of employee involvement. Because of this fundamental disagreement, they were unable to launch a common proposal. Therefore, the final outcome of any initiative would be difficult to predict in the diverse European polity that allows for multiple lobbying activities. Neither side is interested in putting the status quo at risk and possibly jeopardizing its position. All in all, there is no pressure to be expected from the national level on the Commission.

Third, the Commission, whose task it is to monitor the Treaties, does not constitute a coherent and unitary corporate actor (Christiansen, 1996). In our case, jurisdiction and responsibilities are legally divided between two of its departments: DG Employment, Social Affairs and Inclusion is in charge of the SE Directive, while DG Internal Market and Services oversees the SE Regulation. Such a constellation is by no means unique in Commission politics. However, in all cases of disagreement it creates difficulties for 
forms of interest intermediation and viable compromises between individual DGs. Therefore, it is unlikely that the Commission will take the political leadership and initiate amendments.

Last but not least, unanimous decisions in the Council of Ministers constitute a necessary prerequisite that, as the already mentioned protracted history of the SE obviously indicates, is nearly impossible to reach. Political interest has shifted away from the SE to additional legal forms of European regulation such as European Cooperative Society, Cross Border Merger Directive, European Private Company Statute or the Singlemember Companies (Cremers, 2013a; Van het Kaar, 2011). Currently, the discussion is mainly focused on the European Company Law package which aims to introduce new rules for cross-border conversions, transfers of seat and divisions (European Commission, 2018). The proposal for securing board-level employee representation in cross-border instances, however, also lacks a dynamic element to solve the existing problem that initial procedures become frozen (ETUC, 2018).

\section{Outlook}

For all the reasons indicated, the necessary amendments are unlikely to occur in the highly fragmented multi-level European polity. At present, there are too few proponents for a change in the legal frame of reference. Therefore, the SE Directive can hardly realize its originally intended utility and contribution for the development of European industrial relations and corporate governance. Furthermore, it cannot play its role as an integrated part for the establishment of 'social Europe'.

However, non-decisions on existing problems at the European level must not necessarily be the final answer. All Directives do and must provide political leeway and ample room for national manoeuvring in processes of parliamentary decision-making. The reasons are the existence and prevalence of major differences in existing national legislation as well as in 'custom and practice'. Therefore, protracted processes of transposition involve more than just fine-tuning, and open considerable choices for stakeholders at the national level. However, Member States are basically free to make use of their political means and options in order to initiate amendments of their transposition laws.

For the time being, the only realistic alternative consists in adjustments at the national level, through substantial amendments of national transposition laws (including specification of 'structural changes'). Because of the indicated geographical distribution, this requirement refers especially but not exclusively to Germany (SE-Beteiligungsgesetz). However, the SE has played only a strictly limited role in the current German discourse (Deutscher Bundestag, 2016). Nevertheless, this idea constitutes a suitable solution because 'structural changes' have been specified in the transposition laws of Austria, Belgium and Poland.

\section{Acknowledgements}

The authors thank Roland Köstler, Lasse Pütz and two anonymous reviewers for valuable critique and helpful suggestions. 


\section{Funding}

The author(s) received no financial support for the research, authorship and/or publication of this article.

\section{Notes}

1. A similar policy solution was earlier applied in the Directives on European Works Councils (Jagodziński, 2013). A detailed analysis of SEWC practices, as well as comparisons between SEWCS and EWCs in operation (De Spiegelaere and Jagodziński, 2015) is beyond the scope of our analysis.

2. This latter group also includes 'shelf' SEs, inactive companies which may be activated by acquiring employees and operations (Stollt and Kelemen, 2013). Given the lack of data, the ECDB no longer provides separate numbers for these.

3. There are parallels with the earlier case of the 1994 EWC Directive, which also prescribed a review after 5 years; in fact it took another decade before the recast Directive came into force in 2009 (Waddington, 2011).

\section{References}

Arbeitskreis Unternehmerische Mitbestimmung (2009) Entwurf einer Regelung zur Mitbestimmungsvereinbarung sowie zur Größe des mitbestimmten Aufsichtsrats. Zeitschrift für Wirtschaftsrecht 30(19): 885-898.

Bamber GJ, Lansbury RD, Wailes N and Wright CF (eds) (2016) International and Comparative Employment Relations: National Regulation, Global Changes, 6th edn. London: SAGE.

BDA/BDI (2004) Bericht der Kommission Mitbestimmung: Mitbestimmung modernisieren. Berlin: BDA/BDI.

Casey C, Fiedler A and Fath B (2016) The European Company (SE): Power and participation in the multinational corporation. European Journal of Industrial Relations 22(1): 73-90.

Christiansen T (1996) A maturing bureaucracy? The role of the Commission in the policy process. In: Richardson J (ed.) European Union: Power and Policy-Making. London: Routledge, pp. 77-95.

Cremers J (2011) Are you being served? The consultation procedure on the functioning of the European Company Statute. Transfer 17(2): 269-274.

Cremers J (2013a) European initiatives for other corporate forms. In: Cremers J, Stollt M and Vitols S (eds) A Decade of Experience with the European Company. Brussels: ETUI, pp. 251-271.

Cremers J (2013b) The EU assessment of the SE corporate form. In: Cremers J, Stollt M and Vitols $\mathrm{S}$ (eds) A Decade of Experience with the European Company. Brussels: ETUI, pp. 229-250.

Cremers J and Carlson A (2013) SEs in the Czech Republic. In: Cremers J, Stollt M and Vitols S (eds) A Decade of Experience with the European Company. Brussels: ETUI, pp. 107-122.

Cremers J, Kluge N and Stollt M (2010) Worker Participation: A 'Burden' on the European Company (SE)? A Critical Assessment of an EU Consultation Process. Brussels: ETUI.

De Spiegelaere S and Jagodziński R (2015) European Works Councils and SE Works Councils in 2015: Facts \& Figures. Brussels: ETUI.

Deutscher Bundestag (2016) Antrag der Abgeordneten Beate Müller-Gemmeke et al.und der Fraktion BÜNDNIS 90/DIE GRÜNEN Unternehmensmitbestimmung stärken: Grauzonen schließen (Drucksache 18/10253, 18. Wahlperiode 09.11.2016). Berlin: Deutscher Bundestag. Available at: http://dipbt.bundestag.de/doc/btd/18/102/1810253.pdf 
Eidenmüller H and Lasák J (2012) The Czech Societas Europaea Puzzle. Journal of Corporate Law Studies 12(2): 237-254.

Ernst \& Young (2009) Study on the Operation and the Impacts of the Statute for a European Company (SE). 2008/S 144-192482 Final Report, 9 December. Brussels: European Commission.

ETUC (2014) Towards a new framework for more democracy at work. Resolution adopted at the Executive Committee meeting, 21-22 October. Available at: https://www.etuc.org/documents /towards-new-framework-more-democracy-work-etuc-resolution\#.WnsM2q7ibIU

ETUC (2018) The new company law package 2018: A missed opportunity for more democracy at work, 28 June. Available at: https://www.etuc.org/en/document/etuc-position-paperthe-new -company-law-package-2018-missed-opportunity-more-democracy-work

ETUI (2018) European Company Database (ECDB). Available at: http://ecdb.worker-participa tion.eu

European Commission (2010) Synthesis of the Comments on the Consultation Document of the Internal Market and Services Directorate General on the Results of the Study on the Operation and the Impacts of the Statute for a European Company (SE). Brussels: European Commission.

European Commission (2018) Company Law package. Available at: https://ec.europa.eu/info /publications/company-law-package_en

Falkner G, Treib O, Hartlapp M and Leiber S (2005) Complying with Europe: EU Harmonization and Soft Law in the Member States. Cambridge: Cambridge University Press.

Frege C and Kelly J (eds) (2014) Comparative Employment Relations in the Global Economy. London: Routledge.

Fulton L (2013) From a European blueprint to national law. In: Cremers J, Stollt M and Vitols S (eds) A Decade of Experience with the European Company. Brussels: ETUI, pp. 67-89.

Gold M (2011) 'Taken on board': An evaluation of the influence of employee board-level representatives on company decision-making across Europe. European Journal of Industrial Relations 17(1): 41-56.

Gold M and Schwimbersky S (2008) The European Company Statute: Implications for industrial relations in the European Union. European Journal of Industrial Relations 14(1): 46-64.

Hans-Böckler-Stiftung (2018) SE-Datenblatt. Düsseldorf: Hans-Böckler-Stiftung. Available at: https://www.boeckler.de/pdf/pb_mitbestimmung_se_2018_6.pdf

Höland A (2000) Mitbestimmung in Europa: Rechtliche und politische Regelungen. Frankfurt am Main: Campus.

Jagodziński R (2013) The EWC directives and the SE legal framework: Symbiosis and mutual reinforcement brought to a halt? In: Cremers J, Stollt M and Vitols S (eds) A Decade of Experience with the European Company. Brussels: ETUI, pp. 273-289.

Keller B (2002) The European Company Statute: Employee involvement - and beyond. Industrial Relations Journal 33(5): 423-445.

Keller B and Werner F (2010) Industrial democracy from a European perspective: The example of SEs. Economic and Industrial Democracy 31(Suppl. 4): 40-54.

Keller B and Werner F (2012) New forms of employee involvement at European level: The case of the European Company (SE). British Journal of Industrial Relations 50(4): 620-643.

Köstler R (2013) SEs in Germany. In: Cremers J, Stollt M and Vitols S (eds) A Decade of Experience with the European Company. Brussels: ETUI, pp. 123-131.

Lasák J (2018) Report from the Czech Republic: Shareholders' rights at Czech Joint-Stock Companies' general meetings'. European Company Law 15(3): 90-96. 
Rehfeldt U, Voss E, Pulignano V, Kelemen M, Telljohann V, Fulton L, Neumann L, Mester D, Schütze K and Wilke P (2011) Employee Involvement in Companies Under the European Company Statute. Luxembourg: Publications Office.

Rose E (2013) The workers' voice in SE agreements. In: Cremers J, Stollt M and Vitols S (eds) $A$ Decade of Experience with the European Company. Brussels: ETUI, pp. 207-225.

Rosenbohm S (2013) The SE's impact on transnational information and consultation: Trends and developments from a company perspective. In: Cremers J, Stollt M and Vitols S (eds) $A$ Decade of Experience with the European Company. Brussels: ETUI, pp. 189-205.

Rosenbohm S (2014) Verhandelte Mitbestimmung: Die Arbeitnehmerbeteiligung in der Europäischen Aktiengesellschaft. Frankfurt am Main: Campus.

Schwimbersky S and Gold M (2013) The European Company Statute: A tangled history. In: Cremers J, Stollt M and Vitols S (eds) A Decade of Experience with the European Company. Brussels: ETUI, pp. 49-66.

Stollt M and Kelemen M (2013) A big hit or a flop? A decade of facts and figures on the European Company (SE). In: Cremers J, Stollt M and Vitols S (eds) A Decade of Experience with the European Company. Brussels: ETUI, pp. 25-47.

Stollt M and Kluge N (2011) The potential of employee involvement in the SE to foster the Europeanization of labour relations. Transfer 17(2): 181-191.

Van het Kaar R (2011) The European Company (SE) Statute: Up against increasing competition. Transfer 17(2): 193-201.

Von der Höh RM (2017) Die Vorrats-SE als Problem der Gesetzesumgehung und des Rechtsmissbrauchs. Baden-Baden: Nomos.

Von Werder A (2004) Modernisierung der Mitbestimmung. Die Betriebswirtschaft 64(2): 229-243.

Waddington J (2011) European Works Councils and Industrial Relations: A Transnational Industrial Relations Institution in the Making. London: Routledge.

Waddington J and Conchon A (2017) Is Europeanised board-level employee representation specific? The case of European Companies (SEs). Working Paper 2017.02. Brussels: ETUI.

Weber S (2013) Sektorale Sozialdialoge aufEU-Ebene. Supranationale und nationale Perspektiven. Baden-Baden: Nomos.

Weiß D (2016) Arbeitnehmermitbestimmung und die Europäische Aktiengesellschaft: Eine empirische Analyse auf Länderebene. German Journal of Human Resource Management: Zeitschrift für Personalforschung 30(2): 84-107.

Weiss M (2008) Labour law and the future of social Europe. Canadian Labour \& Employment Law Journal 14(2): 159-186.

\section{Author biographies}

Berndt Keller is Professor Emeritus of Employment Relations at the University of Konstanz.

Sophie Rosenbohm is a Post-Doctoral Researcher at the Institute for Work, Skills and Training (IAQ) at the University of Duisburg-Essen. 
DuEPublico

Duisburg-Essen Publications online
UNIVERSITÄT $D_{E} U_{S} S_{S} B_{N} U R$ G

offen im Denken

Ub | $\begin{aligned} & \text { universitäts } \\ & \text { bibliothek }\end{aligned}$

This text is made available via DuEPublico, the institutional repository of the University of Duisburg-Essen. This version may eventually differ from another version distributed by a commercial publisher.

DOI: $\quad 10.1177 / 0959680118825057$

URN： urn:nbn:de:hbz:464-20201125-163953-1

In: European Journal of Industrial Relations 2020, Vol. 26(1) 23-39.

https://doi.org/10.1177/0959680118825057

This publication is with permission of the rights owner freely accessible due to an Alliance licence and a national licence (funded by the DFG, German Research Foundation) respectively.

All rights reserved. $\quad$ (C) The Author(s) 2019 